\title{
Role of Two Different Annealing Temperatures in Genetic Variability Determination of Pseudomonas aeruginosa
}

\author{
Ghada A. Mohammad \\ Department of Biology /College of Science/ University of Mosul
}

(Received 27/ 1 / 2014 ; Accepted 26 / 5 / 2014)

\begin{abstract}
Seven isolates of Pseudomonas aeruginosa were obtained from bacterial strain bank department of Biology/ College of Science/ Mosul University. The DNA was extracted from bacterial culture. Genetic variability was achieved by (RAPD-PCR), and ERIC2 primer was used. Two programs were used in thermal cycling containing two different annealing temperatures, the first was $50^{\circ} \mathrm{C}$, its amplification and electrophoresis results showed that all seven isolates had no band except the isolate No. (3) which has revealed a band (approximately $600 \mathrm{bp}$ ) when compared with DNA ladder, so this temperature was not suitable for detection of genetic variation for our local bacteria.

The annealing temperature for the second program was $35^{\circ} \mathrm{C}$, its amplification and electrophoresis result has illustrated that there are genetic variability among just three isolates which had number 2, 3, and 4, while the other isolates have failed to show any band. So, the $35^{\circ} \mathrm{C}$ was better than $50^{\circ} \mathrm{C}$ to determine genetic variation in this study.
\end{abstract}

Keywords: Genetic variation, P.aeruginosa, RAPD-PCR, ERIC2 primer.

\section{دور درجتي تلان في تعيين التباين الوراثي للزوائف الزنجارية}

\begin{abstract}
الملخص
استخدمت سبع عزلات من جرثومة P.aeruginosa نم الحصول عليها من بنك السلالات البكتيرية/ قسم علوم الحياة/

كلية العلوم/ جامعة الموصل. استخلص الـ DNA من المزارع الجرثومية للعزلات للكثف عن التباين الوراثي لها باستخدام تقنية مؤشرات التضاعف العشوائي المتعدد الأشكال لا DNA وباستخدام البادئ ERIC2. اعتمد برنامجين يحويان درجتي تلان

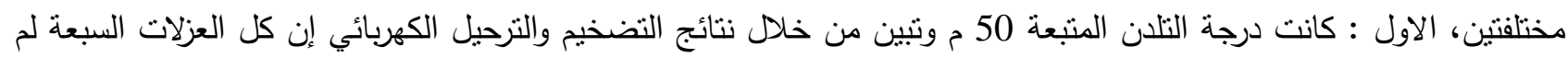
تظهر حزم تضاعف ماعدا العزلة رقم 3 التي اظهرت حزمة بوزن جزيئي مقاربا لا 600 زوج قاعدي عند مقارنتها مع مؤشر

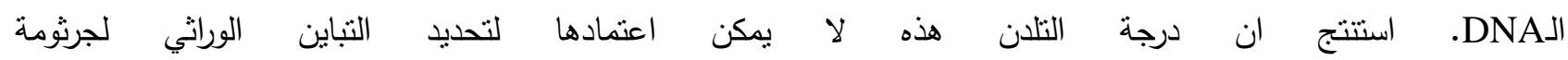
P. aeruginosa من العزلات السبع تلك التي تحمل الارقام 2 و 3 و4 2 حيث اظهرت حزم تضاعف متعددة فيما أخفقت باقي العزلات من إظهار أية حزمة. لذا فان درجة 35 م كانت أفضل من درجة 50 م للكثف عن التباين الوراثي في هذه الدراسة.
\end{abstract}

الكلمات الدالة: التباين الوراثي، الزوائف الزنجارية، مؤشرات التضاعف العشوائي المتعدد الأشكال للأDNA، البادئ ERIC2 


\section{INTRODUCTION}

Due to the plasticity of the phenotypic characteristics, molecular techniques (which are inherently more stable than phenotypic characteristics) have gained popularity for strain differentiation and epidemiological studies of many organisms (Deschaght et al., 2011).

Molecular typing of microbial pathogens is of pivotal importance in the elucidation of transmission routes, detailed genetic analysis at the species level gives insights into the variability within a bacterial population and generates evidence on genome plasticity and evolution, which in turn leads to bacterial adaptation to various environmental conditions. (Renders et al., 1996)

For the last two decades, PCR-based genotyping methods have played an important role in bacterial typing schemes. One of the PCR-based methods, namely random amplification of polymorphic DNA (RAPD)-PCR, also known as arbitrarily primed-polymerase chain reaction (APPCR), has been described to be useful on account of its simplicity and utility for analysis of large throughput samples (Gürtlet and Mayall, 2001).

Molecular research has been performed to study diversity among $P$. aeruginosa strains, polymorphism of certain of its genes and also genetic comparison of $P$. aeruginosa isolates from different hosts and environments (Onasanya et al., 2010 ; Al-Zahrani et al., 2012). The aim of the present study was to determine the genetic variation of seven clinical isolates of P. aeruginosa by random amplification of polymorphic DNA technique -using two annealing temperatures $50{ }^{\circ} \mathrm{C}$ and $35^{\circ} \mathrm{C}$ which may give a significant look into the interrelationship of these bacterial isolates that in turn leads to investigate the risk of patient-to-patient transmission.

\section{MATERIALS AND METHODS}

Bacterial strains: Seven $P$. aeruginosa isolates were obtained from Bacterial strain bank/ Biology department/ college of science/ Mosul university) collected from the different clinical samples.

Colonies having the typical $P$. aeruginosa morphology were selected and placed in selective and differential media. Biochemical testing was performed to determine the bacterial genus and species, So the purity and identity of each isolate were confirmed by standard microbiological methods.(Forbes et al., 2007 ; Todar, 2011).

\section{Preparation of Chromosomal DNA}

The DNA was extracted from bacterial culture of $P$. aeruginosa using the method of phenolchloroform procedure (Ausubel et al., 2002). DNAs were stored at $-20{ }^{\circ} \mathrm{C}$ until use.

\section{Baterial DNA Amplification:}

1- The Primer: The RAPD primer ERIC2 (enterobacterial repetitive intergenic consensus) sequence (5' - AAG TAA GTG ACT GGG GTG AGC G - 3') which is considered as universal primer has been used according to (Tazumi et al., 2009; Van daele et al., 2006; Speijer et al., 1999 ; Renders et al., 1996). The primer was supplied by BIONEER company as a lyophilized product of picomoles concentration, BIONEER company protocol was adopted for primer resuspension to bring as a final concentration to 5 picomoles/ $\mu 1$ with nuclease-free water.

2- Reaction solution: Twenty five $\mu$ l PCR reaction mix contained the ingredients listed in Table (1)

Table 1: preparation of $25 \mu \mathrm{l}$ of reaction solution

\begin{tabular}{|l|c|c|}
\hline \multicolumn{1}{|c|}{ Component } & Volume & Final Conc. \\
\hline GpTag $^{\circledR}$ Green Master Mix, 2X & $12.5 \mu l$ & $1 \mathrm{X}$ \\
\hline Primer & $5 \mu \mathrm{l}$ & $5 \mathrm{pmols} / \mu \mathrm{l}$ \\
\hline DNA tamplet & $2 \mu \mathrm{l}$ & $<250 \mathrm{ng}$ \\
\hline Nuclease-Free Water to & $25 \mu \mathrm{l}$ & N.A \\
\hline
\end{tabular}


Twenty Five $\mu$ l PCR reaction solution was prepared according to Go Taq ${ }^{\circledR}$ Green Master Mix company (Promega, USA). A negative control without template DNA was used in the reaction.

3- Thermal Cycling conditions (Program):two programs have been dependent to achieve amplification: The First, according to (Tazumi et al., 2009) using thermocycler (Eppendrof AG 22331 Hamburg, Germany, Master Cycler personal) as shown in Table 2.

Table 2: RAPD-PCR amplification condition for first program

\begin{tabular}{|c|c|c|c|c|}
\hline No. & Steps & Temperature & Time & No. of cycles \\
\hline 1 & Denaturation 1 & $94^{\circ} \mathrm{C}$ & $5 \mathrm{~min}$. & 1 \\
\hline \multicolumn{5}{|c|}{ First loop } \\
\hline 2 & Denaturation 2 & $94^{\circ} \mathrm{C}$ & \multirow{3}{*}{$\begin{array}{l}1 \mathrm{~min} . \\
1 \mathrm{~min} . \\
1 \mathrm{~min} .\end{array}$} & \multirow{3}{*}{40 cycles } \\
\hline 3 & Annealing & $50^{\circ} \mathrm{C}$ & & \\
\hline 4 & Primary Extension & $72^{\circ} \mathrm{C}$ & & \\
\hline 5 & Final Extension & $72^{\circ} \mathrm{C}$ & $10 \mathrm{~min}$. & 1 \\
\hline
\end{tabular}

At the end of the first amplification, $(10 \mu \mathrm{l})$ were removed from each reaction mixture and examined by electrophoresis $(100 \mathrm{~V}, 90 \mathrm{~min})$ (ENDURO ${ }^{\mathrm{TM}}$ electrophoresis system, ENDURO power supplies, Labnet international. Inc. model: E 0303, Taiwan.) in gels composed of 2\% (w/v) agarose stained with ethidium bromide $(5 \mu \mathrm{g} / 100 \mathrm{ml})$ by using TAE buffer $(40 \mathrm{mM}$ Tris, $20 \mathrm{mM}$ acetic acid, 1mM EDTA, $\mathrm{pH}$ 8.3), Stained agarose gel was visualised under UV illumination by (UV transilluminator, model MUV 21-312, Taiwan). A photograph was taken by using digital camera (Canon, Japan). The molecular weights of bands were estimated by using standard molecular markers (100 bp DNA Ladder, BIONEER).

The second amplification was changed just in annealing temperature of $35^{\circ} \mathrm{C}$ (Table 3) according to (Van daele et al., 2006; Van daele et al., 2005; Ortiz-Herrera, 2004)

\section{Table 3: RAPD-PCR amplification condition for second program}

\begin{tabular}{|c|c|c|c|c|}
\hline No. & Steps & Temperature & Time & No. of cycles \\
\hline 1 & Denaturation 1 & $94^{\circ} \mathrm{C}$ & $5 \mathrm{~min}$. & 1 \\
\hline \multicolumn{5}{|c|}{ First loop } \\
\hline 2 & Denaturation 2 & $94^{\circ} \mathrm{C}$ & \multirow{3}{*}{$\begin{array}{l}1 \mathrm{~min} . \\
1 \mathrm{~min} . \\
1 \mathrm{~min} .\end{array}$} & \multirow{3}{*}{ - 40 cycles } \\
\hline 3 & Annealing & $35^{\circ} \mathrm{C}$ & & \\
\hline 4 & Primary Extension & $72^{\circ} \mathrm{C}$ & & \\
\hline 5 & Final Extension & $72^{\circ} \mathrm{C}$ & $10 \mathrm{~min}$. & 1 \\
\hline
\end{tabular}

Then the procedure was completed as previous steps and the reaction mixture was completed as explained in the first program.

\section{RESULTS AND DISCUSSION}

After the extraction of genomic DNA from the seven $P$. aeruginosa isolates, it was amplified by RAPD-PCR using ERIC2 primer, then the products were separated by electrophoresis to study genetic variation in these local bacterial isolates.

The results of the first program did not give successful finding as seen in (Fig. 1); All seven isolates did not appear any band except the isolate No. (3) which has showed a band with molecular weight of approximately $600 \mathrm{bp}$ compared with $100 \mathrm{bp}$ DNA ladder (lane 3 in Fig. 1), so the isolate number (3) was different from the other six isolates by this band only. The absence of bands for 
other six isolates might be attributed to lack of complementary sequences to the primer in this temperature among the genomic DNA from P.aeruginosa (Devos and Gale, 1992).

The present study concluded that this temperature is not the optimum for determination the genetic variation of our bacterial isolates.

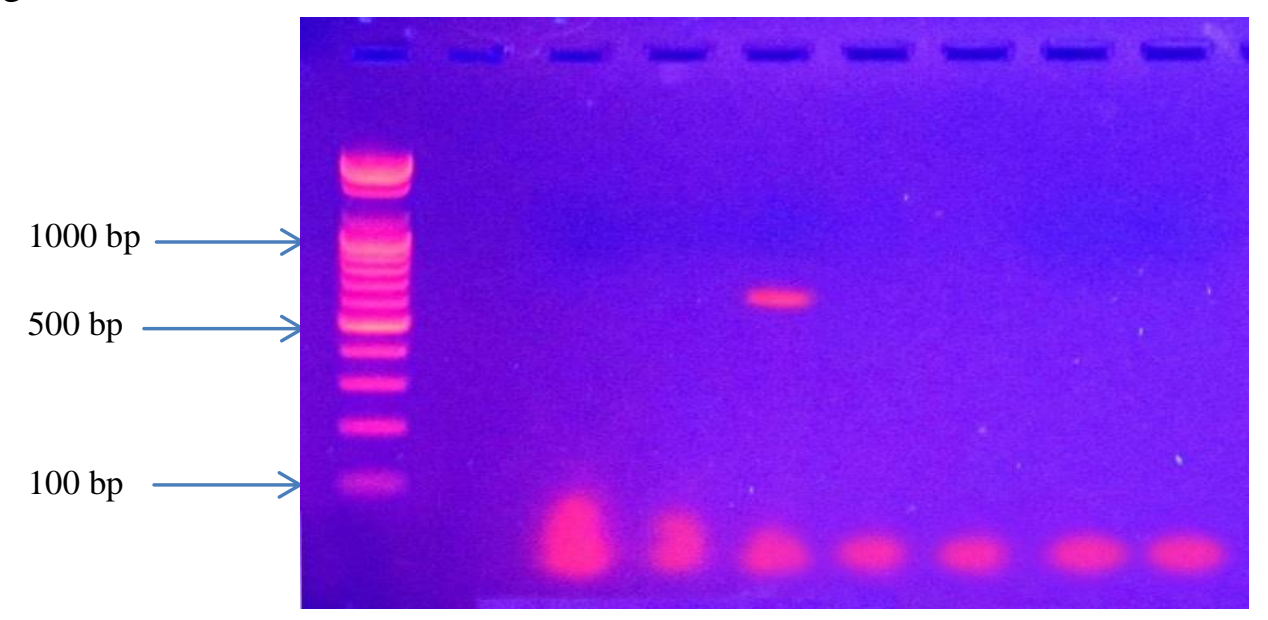

Fig. 1: Agarose gel electrophoresis of RAPD PCR amplification for P.aeruginosa isolates. Lanes: M, mw marker; -ve, negative control; 1-7 P.aeruginosa DNA (annealing temp. in PCR program was $50^{\circ} \mathrm{C}$ )

Although it has been reported by various groups that RAPD typing is reproducible, historically there have been several reports of problems associated with its reproducibility. Grif et al. (1998) reported that RAPD suffered from the lack of standardization using different methods in different laboratories and this may affect the quality of results. RAPD-PCR can also suffer from the same factors that affect ordinary PCR, including magnesium concentration, primer and reagent 'batch-to-batch' variation, annaeling temperature. and quality of the thermal cycler. Power (1996) suggested that for RAPD to be a definitive typing technique, the reproducible generation and interpretation of RAPD fingerprints needs to be developed, to achieve this criterion, the use of an automated system for DNA preparation combined with the use of manufactured RAPD master mixes, as well as use of the same thermal cycler and standard (Jamasbi and Proudfoot, 2008).

According to a previous result, annealing temperature was decreased to $35^{\circ} \mathrm{C}$ according to the researchers(Van daele et al., 2006; Van daele et al., 2005).

In attempt to detect on distinct genetic variations among the isolates, $35^{\circ} \mathrm{C}$ was shown to be better than $50^{\circ} \mathrm{C}$ in demonstrating the genetic variations among the isolates.

Variations among studied isolates and RAPD results analysis are achieved by depending on presence or absence of amplified bands, also by the difference of molecular weights for these bands which differ by different sites number complemented to primer sequence on genomic DNA, and also differ by the distance between site and another (Mayer et al., 1997).

Our PCR products data indicated high diversity of $P$. aeruginosa, by using the primer ERIC2, this study showed the presence of genetic variation in just three isolates among P.aeruginosa as can be seen in (Fig. 2). Results analysis for polymorphism is usually scored in three different forms in experiments: presence or absence of amplified DNA bands, differences in molecular weight of amplified DNA bands and differences in the intensity of amplified bands (Bardakci, 2001).

The isolate No.4 revealed a largest numbers of amplified bands ( 6 bands) represented by $<100,300,365,410,800$ and 1000 bp. while the isolate No. 2 had four amplified bands represented by <100, 300, 400 and $600 \mathrm{bp}$, but three bands (100, 400, $650 \mathrm{bp}$ ) for the isolates No.3. ( Table 4). This indicates that the primer has found specific areas that bind it along with the DNA template, consequently amplification of the fragments was achieved, bands have appeared, and finally polymorphism has demonstrated. 
The other isolates of $P$. aeruginosa (which had number 1, 5, 6, and 7) had no revealed bands.

This technique utilizes a variable short length arbitrary primer, and is advantageous, as it does not require any previous knowledge of the target DNA sequence data. The primer is amplified arbitrarily at low stringency, where the oligonucleotide binds at complementary and partially mismatched sites and generates bands which differ in length and nucleotide composition. (Tazumi et al., 2009).

As the primer efficiency depends on the total number of bands amplified by the primer and this could include a number of common ones (representing conserved) sequences among various species, efficiency would not be very informative in identifying species. in generating patterns of banding that are unique to the species and second in exhibiting or lacking unique band (s) that distinguish an individual from the rest of the population (Dhahi et al., 2011)

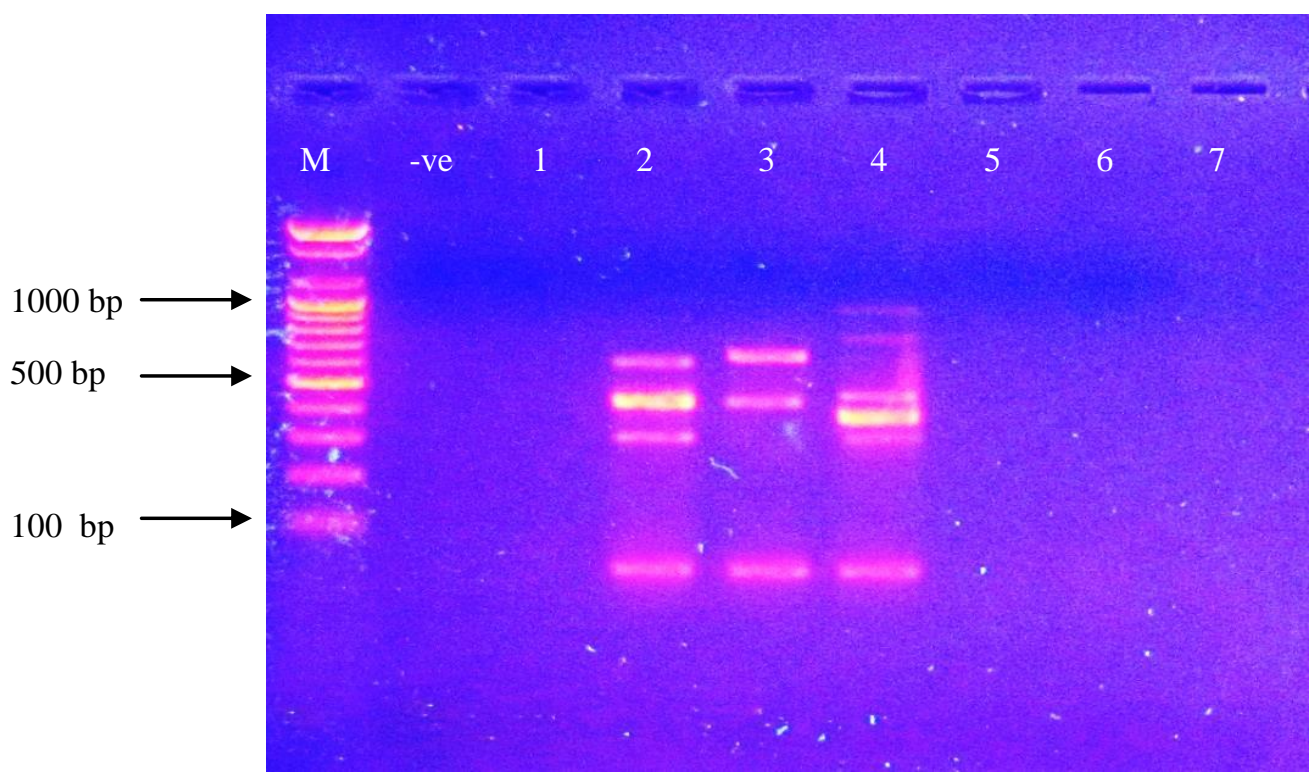

Fig. 2: Agarose gel electrophoresis of RAPD PCR amplification for P.aeruginosa isolates. Lanes: M, mw marker; -ve, negative control; 1-7 P.aeruginosa DNA (annealing temp. in PCR program was $35^{\circ} \mathrm{C}$ )

Table 4: Molecular weights(bp) of the amplified fragments of isolates 2, 3, and 4. Lanes 2, 3 and 4 respectively.

\begin{tabular}{|c|c|c|c|c|}
\hline \multirow{2}{*}{ Type of band } & \multirow{2}{*}{$\begin{array}{c}\text { Molecular weights of } \\
\text { bands (bp) }\end{array}$} & 2 & 3 & 4 \\
\cline { 3 - 5 } & 1000 & 0 & 0 & 1 \\
\hline Polymorphic & 800 & 0 & 0 & 1 \\
\hline$=$ & 650 & 0 & 1 & 0 \\
\hline$=$ & 600 & 1 & 0 & 0 \\
\hline$=$ & 410 & 0 & 0 & 1 \\
\hline$=$ & 400 & 1 & 1 & 0 \\
\hline$=$ & 365 & 1 & 0 & 1 \\
\hline$=$ & 300 & 1 & 0 & 1 \\
\hline$=$ & $<100$ & 4 & 1 & 1 \\
\hline monomorphic & 9 bands & 0 & 3 & 6 \\
\hline Total & & & & 0 \\
\hline
\end{tabular}

0 :abscence of band

1 : presence of band 
This technique uses random primers under low specificity conditions; it is less costly and faster and easier to perform than analogous systems, either phenotypic or genotypic.(Loutit and Tompkins, 1991)

Polymorphisms at DNA level may occur as a result of several types of mutations, such as single base change in the primer-annealing site in the genome that prevents amplification by introducing a mismatch at $3^{\prime}$ end of a DNA segment (Hurtado and Rodriguwz, 1999). Other sources of polymorphisms may include deletion of a priming site, insertion that render priming sites to be too distant to support amplification, or they may change the size of DNA segment without preventing its amplification (Williams et al., 1990).

Multidrug resistance (MDR) is a common feature of $P$. aeruginosa strains. Rapid identification of the organism is necessary to expedite the onset of treatment and to reduce the duration and dosage of antibiotic therapy, which in turn could minimize the development of antibiotic resistance. (Jamasbi and Poudfoot, 2008)

A significant decline in susceptibility of $P$. aeruginosa to B-lactams, aminoglycosides, and quinolones has been reported, Nosocomial outbreaks MDR in different hospitals have appeared that the frequency and rate of resistance to individual antibiotics are different in different genotype (Gales et al., 2001).

The differences in antibiotic susceptibility of $P$. aeruginosa in different genetic variations could be attributed to the differences in patient population, the duration of hospitalization, cross-infection, and the dose and types of antibiotics. Transmission of resistant fragments within smaller hospital units may be responsible for this phenomenon, and the determination of antimicrobial profiles is another typing method used frequently as a supplemental epidemiological tool for strain differentiation of $P$. aeruginosa. It should be noted, however, that antibiotic susceptibility profiles are less stable than $\mathrm{O}$-antigenic markers, given the resistance factors that can occur under pressure of antibiotic therapy. (Jamasbi and Poudfoot, 2008).

\section{REFERENCES}

Al-Zahrani, S.; Aly, N.; Al-Harbi, M.(2012). Genetic characterization of Pseudomonas aeruginosa isolated from contact lenses and other sources by RAPD analysis. Life Science J., 9(1), 835843.

Ausubel, F.M.; Brent, R.; Kingston, R.E.; Moore, D.D.; Seidman, J.G.; Smith, J.A.; Struhl, K. (2002). "Short Protocols in Molecular Biology" $5^{\text {th }}$ ed.John Wiley and Sons, Inc, USA.

Bardakci, F. (2001). Random Amplified Polymorphic DNA (RAPD) Markers. Turk. J. Biol. Rev., 185-196.

Deschaght, P.; Van Simaey, L.; Decat, E.; Van Mechelen, E.; Brisse, S.; Vaneechoutte, M. (2011). Rapid genotyping of Achromobacter xylosoxidans, Acinetobacter baumannii, Klebsiella pneumoniae, Pseudomonas aeruginosa and Stenotrophomonas maltophilia isolates using melting curve analysis of RAPD-generated DNA fragments (McRAPD) Research in Microbiology. 1623, 386-392.

Devos, K.M.; Gale, M.D. (1992). The use of random amplified polymorphic DNA markers in wheat. Theo. Appl. Genet., 84, 567-572.

Dhahi, S.; Al-Assie, A.; Omear, H.(2011). Application of the randomly amplified polymorphic DNA (RAPD) markers to analyze the genetic variability in species of the fungus Alternaria. Raf. Sci. J. 22,1- 16.

Forbes, B.A.; Sahm, D.F.; Weissfeld, A.S. (2007). "Bailey and Scott's Diagnostic Microbiology". $12^{\text {th }}$ ed. Mosby, Inc., St. Louis. pp. 97, 120.

Gales, A.C.; Jones, R.N.; Turnidge, J. (2001). Characterization of Pseudomonas aeruginosa isolates: Occurrence rates, antimicrobial susceptibility patterns, and molecular typing in the Global SENTRY Antimicrobial Surveillance Program, 1997-1999. Clin Infect Dis. 32, S146S155. 
Grif, K.; Karch, H.; Schneider, C. (1998). Comparative study of five different techniques for epidemiological typing of Escherichia coli O157. Diag Microbiol Infect Dis. 32(3), 165-176.

Gürtler, V.; Mayall, B.C. (2001) Genomic approaches to typing, taxonomy and evolution of bacterial isolates. Int. J. Sys Evol. Microbiol. 51(1), 3-16.

Jamasbi, R.J.; Proudfoot, E.M. (2008). Phenotypic and genotypic characteristics of clinical isolates of Pseudomonas aeruginosa: rate of occurrence and distribution of different serotypes, antimicrobial susceptibility profiles. American Society for Clinical Pathology, Laboratory Medicine. 39(3), 155-161.

Loutit, J.S.; Tompkins, L.S. (1991). Restriction enzyme and Southern patients. J. Clin. Microbiol. 33, 2216-2219.

Mayer, M.S.; Tullu, A.; Simon, C.J.; Kumar, J.; Muehlbauer, W.H. (1997). Development of DNA marker for fusarium resistance in chickpea in :Vdupa, S.M. and Wigand, F. DNA markers and breeding for resistance to ascochyta in chickpea. Proceeding of the symposium on " application of DNA fingerprinting for crop improvement: marker-assisted selection for agriculture in dry areas" 11-12 april (1994), ICARDA: Aleppo, Syria. 143-152.

Onasanya, A.; Basso, E.; Somado, E.R.; Gasore, F.E.; Nwilene, E. (2010). Development of a combined molecular diagnostic and DNA fingerprinting technique for rice bacteria pathogens in Africa. Biotechnology. 9, 89-105.

Ortiz-Herrera, M.; Geronimo-Gallegos, A.; Cuevas-Schacht, F.; Perez-Fernandez, L. (2004). RAPD-PCR Characterization of Pseudomonas aeruginosa straind obtained from cystic fibrosis patients. Salud pubica de mexico. 46(2),1-7.

Power, E.G. (1996). RAPD typing in microbiology - a technical review. J. Hosp. Infect., 34(4), 247-265.

Renders, N.U.; Ro“mling, H.; Verbrugh, A.; Van Belkum, A. (1996). Comparative typing of Pseudomonas aeruginosaby random amplification of polymorphic DNA or pulsed-field gel electrophoresis of DNA macrorestriction fragments. J. Clin. Microbiol. 34:3190-3195.

Speijer, H.; Savelkoul, P.; Bonten, M.; Stobberingh, E.; Tjhie, J. (1999).Application of Different Genotyping Methods for Pseudomonas aeruginosa in a Setting of Endemicity in an Intensive Care Unit. Clin. Micribiol. J. 37, 3654-3661.

Tazumi, A.; Maeda, Y.; Buckley, T.; Millar, B.C.; Goldsmith, C.E.; Dooley, J.S.G.; Elborn, J.S.; Matsuda, M.; Moore, J.E. (2009). Molecular epidemiology of clinical isolates of Pseudomonas aeruginosa isolated from horses in Ireland. Irish Veterinary J. 62(7), 456-456.

Todar, K. (2011). "Online Textbook of Bacteriology". University of Wisconsin, Madison, 304, p.1421.

Van daele, S.; Franckx, H.; Verhelst, R.; Schelstraete, P.; Haerynck, F. (2005). Epidemiology of Pseudomonas aeruginosa in a cystic fibrosis rehabilitation centre. Eur.Respir. J. 25, 474-481

Van daele, S.; Vaneechoutte, M.; De Boeck, K.; Knoop, C.; Malfroot, A. (2006). Survey of Pseudomonas aeruginosa genotypes in colonized cystic fibrosis patients. Eur. Respir. J. 28,740-747.

Williams, J.G.; Kubelik, A.R.; Livak, K.J. (1990). DNA polymorphisms amplified by arbitrary primers are useful as genetic markers. Nucleic Acids Res. 18, 6531-6535. 